\title{
Industrial Harmony and Work Discontent: Employer and Employees Relations Perspective
}

\author{
Dr Barinem Wisdom Girigiri ${ }^{1}$, Dr Porbari Monbari Badom ${ }^{2}$ \\ 1E-mail: wisdom4rich@yahoo.com \\ ${ }^{1}$ Department of Sociology, Faculty of Social Sciences \\ Rivers State University, Port Harcourt, 500272, Nigeria. \\ ${ }^{2}$ Department of sociology, Faculty of social sciences \\ University of Port Harcourt, 500272, Nigeria. \\ E-mail: philanluv@yahoo.com
}

\begin{abstract}
This paper explored the nature of industrial harmony as it encompasses industrial democracy and precludes work discontent. Industrial harmony is presented as a sine qua non for human resources' commitment relative to a productive work organization and its absence or failure to its application breeds work discontent and possibly usher in industrial action in work organizations. Industrial harmony can be said to be in operation practically between workers and employer/ management when all actors are given a fair play in matters that concern all and can impinge on the overall performance by workers and as well affects the smooth growth and development of the organization; which in turn distort the objectives and target of management. Conflicts do not just arise in the industrial relations set-up, but do so, as a result of diagonally opposing interest of parties operating in the system. The paper through thorough content analysis and careful observation has shown that to enhance better understanding in the working environment among parties, the creation of separate institutions to be mounted by sound educators, who are to reposition the old thinking in the sense of mutual exclusivity wherein; employer/management makes all decisions when issues arise to focus on mutually inclusiveness involving all parties contributing ideas to have an ideal work environment of 'master-subordinate' as against 'master-servant' relationship. In the light of the foregoing, the study established that if the participating workers are allowed to be involved workers, their jobs become an extension of themselves and by their decision; they are thus creating their work, modifying and regulating it. As they are more involved in their works, they become more committed to it, and derive more satisfaction from it. What is more democratic and by extension, the bedrock of harmonious relationship in industrial setting amongst actors that make the system more than the above?
\end{abstract}

Keywords: Industrial harmony, workplace, democracy, employers, workers, relations, perspective, collective bargaining.

\section{Introduction}

Industrial harmony is a vital component of every modern economic system in the contemporary global society. Its importance derives from a number of functions which it sub-serves. What this means is that a good industrial harmony or peaceful co-existence between workers (Trade Union) and management, at least will definitely showcase a give and take relationship that is mutually inclusive in nature and will in no small measure encourage high workers morale; and by so doing, the performance and Productivity profile of labour will be on the increase. Also, good industrial harmony fosters development of the industrial system and ensures stability in the spheres of governance. This is so, especially with public sector industrial relations, which will have a positive effect in the affairs of private sector (David \& John, 1992).

Usually, where there is cooperation among workers and management in an atmosphere of good industrial understandings, it could lead to political stability which fundamentally lays the foundation for the development of local industries and as well serves as an attraction for foreign investments and invariably create employment for the citizenry (Girigiri, 2002; Girigiri, 2007). The word harmony is defined as the state of peaceful existence; an agreement to be in harmony with our environment; where we live, the business 
place; where we work and to live together in peace socially, economically and politically. In music, the way in which the different notes played or sung together combine to make a pleasing sound. The different noise coming from all the components of music- the bass, the trebor, the tenor, and supranor all coming together to produce harmonious sound called music (Olufemi, n.d.). And this is likened to industrial set-up when actors and all the necessary component parts work together for better result.

In politics or in industry, what concerns all should be brought to the open and be decided upon democratically and harmoniously in the best interest of all. The positive application of democratic principles in matters that concern all, i.e. showing fairness and equality to everyone in the industrial setting and the recognition of their right to take part in decision making, will effectively enhance the industrial atmospheres with less crises or total breakdown (Girigiri, 1999). Industrial harmony is key to organizations progress, growth and expansion. It is crucial for business and people who take decision to invest and those working in the organization will thus have their opinion reflect in the organization. Industrial harmony results when the differences between trade unions on one hand, management or employer on the other can be resolved in the work place without having to resort to total breakdown or closures of the organizations (David \& John, 1992). Put it differently, harmony exist when at all times, parties in relationship in the industrial sphere seek to resolving matters with minimum level of crises bearing in mind the negative consequences on both sides, in case of complete lock-down. The foregoing are some of the essential ingredients for the socioeconomic and political developments which Third World Nations so badly need for work organizations to thrive. Unfortunately, the state of Nigeria industrial relations lack this harmonious value and has not been palatable.

Industrial harmony can be defined as that atmosphere which when in place reduces industrial conflict, as it helps in the establishment of better communication between management and workers (Dabibi, n.d.); where decision making processes involve all interested parties, it will usher in improved creativity, enthusiasm and productivity including better service delivery, and job satisfaction and personal fulfillment will be the hallmarks of employers and workers. Industrial harmony which will certainly lay the foundation for industrial democracy, according to Anugwom (2007) is seen as a means whereby workers have a share in decision affecting the company where they earn a living and therefore have a share in the responsibility for making it successful.

Industrial harmony has to do with the creation of an atmosphere of peaceful and cordial relationship between the workers (Trade Unions) and the management cum government which, and as a matter of necessity is to ensure minimal suspicion in dealing with issues affecting the component parts. Industrial harmony, therefore, calls for a state of peaceful coexistence, where every part or component relevant in the industry must do its best in combination with the other parts to produce an overall pleasing result (Dabibi, (n.d.)). At this juncture, it is pertinent to look at democracy and how it is connected to bringing better industrial relations in work place (Okon, 2008).

Democracy as defined by Lincoln (1809-1865) is government of the people for the people and by the people. The corollary includes political opposition, adult franchise, freedom of speech and assembly. These are the principles of direct democracy, but there is hardly anywhere in the world where direct democracy is practiced. Rather, we can talk about representation democracy. In whatever degree these tenets of democracy hold, we term such societies as democratic. In most of those democratic states, there is always a system of industrial relations which can be called industrial democracy (Clement, 2014; Ima, 2004). Having democratized their political institutions, these societies have gone further to democratize all their social institutions, the end product of which is the democratization of their industrial relations. Industrial democracy is the involvement of staff in making decisions (through structures and processes) which involve the sharing of authority and responsibility in the work Place. Industrial harmony connotes a situation of healthy and cooperative working relationship among all actors in the industrial social context such as employer, government, workers (trade unions), environment (Osamwonyi \& Ugiagbe, 2013). In addition, this covers four broad spectrum of cooperation such as; responsibilities, employment policy, collective bargaining and communication flows (Ladan, 2012). Accordingly, the essence of actors involvement in the affairs of organizations include but not limited to: an understanding of the rationale and purpose of one another and the ability to clearly and effectively communicate with each other freely while also 
accommodating differences within guiding principles to see to the realization of stated objectives and set goals of the organizations (Jinyemiema, 2008). In collaboration with the above, Izidor (2015) stated that actors in industrial relations have different ideologies and aspirations. Therefore, the proper functioning of the system requires that these ideologies and aspirations should be sufficiently compatible and consistent, so as to allow for a common set of ideas which would make for the boundary of actors' role possible, while also limiting their conflict areas of interest.

Organization is a ground accommodating groups of individuals with different socio-cultural backgrounds and characteristics, and as such, achieving a social milieu of lack of biasness and grievances anchored on groups or individual's interest is quite far and a difficult task (Okon, 2008). Therefore, industrial harmony is never an absence or freedom from disagreement, but rather upholds the tenets that, there is an understanding between employers and employees that permits the system to achieve set goals through a medium or avenue agreeable by parties in terms of conflicts/crisis (Izidor, 2015). In the words of Osabuohien \& Ogunrinola (2007) a harmonious workplace is that which guarantees satisfaction of workers' and employers' aspirations through avenue of compromise which is essential for the enhancement of organizational productivity profile and growth. In recent times, industrial relations crisis in Nigeria has assumed unthinkable magnitude. The unceasing crises that have manifestly affected both sectors of public and private lives have posed untold hardship with consequent negative manifestations in the areas of decline in both economic growth and development, massive poverty, retrenchment of workers, etc. (Agba, Ushie \& Agba, 2009). Contributing to this, on the pattern of relationship in the industrial relations circle in Nigeria has been conflictual in nature (Albert \& Yahaya, 2013). This is expressed in the disruptive consequences of it, the significant work stoppages and loss of man hours.

Iheriohanma (2007) asserts that industrial conflicts have bedeviled the industrial atmosphere in the country. Osabuohien \& Ogunrinola (2007) see it from the point of view of absence of peaceful working relationship among actors at the workplace which consequently present conditions that are inimical to organizational success and productivity. To him, these amongst others are; work dissatisfaction that apparently occasioned the issues of absenteeism, strike, high turnover, work-to-rules, low productivity. The challenges which the employer faces in the situation such as presented above and more is how to gain back workers' contentment, dedication to duty, increasing productivity and harmonious working relationship in the organization, especially in the event of an accelerating industrial crisis without recourse to jeopardizing industrial peace (Okon, 2008). Without-much-ado, it is on record that conflict of interest has ever been present in human social existence and it is inevitably difficult to eliminate it completely at workplace; having actors with diagonally opposing interests engaging themselves toward goal attainment. Badom, Anele \& Badey (2018) argued that most of the policies of management and government contrast with the interest of the workers which often result to industrial action. What is more, employers have fashioned different approaches to curb either manifest or latent aspect of the conflictual relationship between them and workers predicated on actual or perceived dishonesty in dealing with matters that concern all. Meanwhile, these approaches have not at all, been achievable in steaming down the rate of industrial discontent in the context of Nigeria works terrain. Notably, for a sound and free industrial culture to operate where employer and workers can engage themselves openly to discuss misgivings, the prevailing conditions must be that of give and take, 'mastersubordinates' and not 'master-servants' culture. Workers should be seen as co-owners and conveyor belt of the wheel of profit and growth and all attendant benefits must be accorded to them. Since disagreement at workplace is from time immemorial, and remain crucial to oil the wheel of relationship, parties should believe that in an event of conflict, it can be addressed in the interest of all; hence harmonious industrial atmosphere is necessary and achievable.

At this juncture, the focus of the paper therefore is to; look into the issues that can bring about harmony at workplace amongst social actors in industrial sphere; examines the conflictual battle grounds that usually put employer and employees at dagger-drawn like attitudinal relationship at workplace; finally, it will explore the place of mutual bargaining in resolving industrial issues. The authors adopted expository content analysis derivable from wide consultations of relevant literature having bearing on the topic under discussion to buttress their points of view through presentation of the factual analysis to the common understanding of all. Also, the careful observations of the authors of the industrial settings and occurrences in a myriad of organizations and their former work organizations enhanced this factual presentation. 


\subsection{Industrial Discontents And Causes}

Girigiri (2008) \& Izidor (2015) stated that Nigerian workers desire security and permanency in their workplace as against casualisation and unusual redundancies that are commonly seen and heard-off. They desire some good measure of love and dealings with fellow co-workers; they want to be seen, recognized and not only heard-off, want acceptance and being fully integrated in every aspect of work. These and more, can be achievable, if workers are properly informed and kept abreast of happenings in the organization. The above are obviously absent because of employers anti-policies against workers, therefore industrial unrests are common visitors to industrial setting. According to Alo (1999) \& Nwokocha (2014), it is an incontrovertible fact that, when and where workers are denied participation in protest against contending issues as a result of dictatorial and authoritarian employer styles of leadership, the outcome on the part of employees will be intolerance, absenteeism, espionage and sabotaging to every effort that seems to subjecting them inhumanly in the work environment. In course of this hanging-in-the-balance scenario, productive capacity of the worker is been affected and thus undermine any progressive process in work organizations until situations normalizes.

Additionally, peace building, maintenance and enthronement of industrial harmony at workplace are a collaborative responsibility on the part of all stakeholders such as the government, the employers, the workers (labour unions), the environment (Onuegbu, 2014). Achieving this can only be realizable on the principle of social dialogue involving necessary stakeholders. Interestingly, however, Mayowa (2015) contends that it is not in any way surprising that in actual practice, organizational policies do not promote the tenet and spirit of mutual partnership anchored on consensus building, and as such, the unfriendly and dehumanizing labour policies are still held bound in organizations. This therefore serves as an engine generating mistrust posing barrier to dialogue, hence tensions and crisis are imminent thereby causing strain in employers and labour-relationship. Albert \& Yahaya (2013) emphasized that where organizations are deficient or lacking in providing adequate mechanism for equalizing differing demands made by social partners, the tendencies and likelihood of conflict of interest approaching a breaking limit is certainly imminent which is capable of interfering with productivity chain and stability of organizations. Suffice to say, where and when employers and workers relations policies degrade the spirit of social justice in organization, ultimately the propensity to crisis situations is already triggered.

Industrial harmony which pragmatically constitutes the preservation of employment can be achieved through the creation of a human work environment. On the other hand, dehumanizing workplace is simply the denial of humanness in working place to others. And this is facilitated by status, power and those being socially connected (Haslam, 2006). Creating humane organizational environment and culture that integrates and embrace new social approach to work by equalizing opportunities for self-development and growth in the work process, while also ensuring befitting quality of work invariably call for good business environment. However, where this sense of humanness has been lost or been beclouded by arrogant nature of employers, the moral exclusion of these necessary demands has a consequential negative effect on the morale and obligation of the employees in terms of putting in their effort for better performance and productivity (Girigiri, 1999; Nwokocha, 2014).

In modern organizations, industrial conflict is inevitable as it were from time immemorial, since the dominant aim of management it is to maximize profits (Makinde, 2013), while labour's main concern is to secure and maintain the highest level of wages with the best conditions of service for their workers. Alan (1970) stated that causes of conflict cannot be discovered simply by reference to the organization and what goes on within it. Managerial, employees' and collectivity of aspirations towards organizational norms mediate a wide diversity of structures, processes, values and norms outside the organization (Makinde, 2013). Managerial action upon the normative system may be determined by external economic forces such as price and wage movement, technological change, market conditions or the industrial structure; by social forces such as rising public expectations of managerial performance, by membership of employers' association, by trade union membership or by political factors such as legislation and government policy. Collectivity aspirations can be shaped by those of wider collectivities externally related by events in the social and economic system generally and by changes in other organizations (Nwibere \& Emecheta, 2009). 
Within the organization, the translation of these external stimuli into effective action upon the social organization, via the perceptions and aspirations of individuals or collectivities, is differently shaped by their location (Drummond, 2000). This is inherently tied to the social organization and access to power, individually or collectively applied. Thus aspirations constantly interact with the nature of the division of labour and the distribution of power produce patterns of conflict.

Arun (2007) stressed that conflict occurs at various levels between and among the various players such as the workers, employers/management and government. Some conflicts are inherent in the industrial structure. Conflicts of interest amongst the various groups are strong enough to cause prolonged work stoppages is ever present. The three main actors in an organization develop different orientations and perceptions of their interests (Girigiri, 2007). The pursuit of divergent objectives by each at the expense of others causes friction severe enough to lead to strikes/Lockouts. These groups, organized or unorganized, manifest their conflicts in various forms which may be overt, while some covert. Other factors which may cause conflict or discontent as Girigiri (1999) opined are wrangling within the union and the awareness by workers of their union officials of improper handling of union fund and also compromised while negotiating union matters with management. It may result in being the underlying factor in a striking situation especially when worker's complaints about the situation are never taken seriously by management (Haralambos \& Healed, 1980).

Accordingly, the basic thought of Karl Marx in his dialectic is the proposition that, at any given point in time, historically; the economic i.e the substructure or the material conditions of the people; their productive capacities structure their social existence and consciousness of that historical epoch. Karl Marx exposition therefore stated thus:

That in every historical epoch, the prevailing mode of economic production and exchange, and the social organization necessarily flowing from it form the basis upon which is build up, and from which alone can be explained, the political and intellectual history of that epoch, that consequently the whole history of mankind depend, (Karl Max, 1990).

Marx is here saying that the mode of production in material life of the people determines the general character of the social, political and cultural processes of life of the people. What this simply means is that, it is the social existence of the people that determines their consciousness and not vice-versa. Therefore, when workers are conscious of being exploited and oppressed by management and government through policies and legislations that seek to suppress them, they resist through the instrumentality of 'trade unions' which consequently may result into conflicting situations and the result may be strike actions, perhaps, closure of the plants.

One singular event that particularly impacted negatively on industrial relations in the country between labour and government and adversely too, affects the economy was the incessant increases in the pump prices of petroleum products, despite the fact that our country, Nigeria is amongst the highest producers in the world (Okon, 2008). The strategic importance of the availability of these products at affordable prices to the socioeconomic activities in Nigeria cannot be over emphasized. The implications of this is that, a hike in their prices impact negatively on the price of other commodities as well as transportation and ultimately, on the standard of living of the populace. This is corroborated by Badom (2019) who found that a hike in the price of petroleum products owing to its scarcity which are corollaries of oil and gas workers' industrial actions caused increased price of commodities and increased fare, It is therefore, not surprising that the attempted deregulation of the downstream sectors of the petroleum industry coupled with government predilection to incessantly increasing the pump prices of petroleum products generates a dramatic running battle between trade union and the state (Girigiri, 2008).

Fashoyin, (2002) contends that Marxian analysis of conflict is attributable to an unending power struggle between workers and their employers over the control of several aspects of work. This results to inequality in the distributions of the proceed of the organization, job insecurity of the workers, and poor management control strategies. Marx therefore, contended that the main source of conflict or social change in organization 
or society is been promoted or prompted by economic influences and not their ideas, ideal or values which human beings hold. This presupposes that good industrial harmony is primarily based on economic (material) well-being of the workers. Looking at the above, perhaps, it seems very clearly that one of the constant industrial conflicts in Nigeria is due largely because of her workers poor economic (material) condition and dehumanizing nature of the working environment. As Damachi (1986) put it that the interest of social partners are not completely mutual. For instance, employer represents, and is mainly concerned with a property interest which in turn is directly related to the financial interest of a limited number of shareholders. The interest of the employees' organization or union is primarily that of workers such as their material, spiritual, social, and psychological needs (Otobo, 2000). The above points out that the employers including their managers on one side and employees on the polar side have diagonally opposing interests at all time, hence conflict situation is inevitable.

\subsection{Measures To Reinforcing Industrial Harmony In Nigeria Industrial Relations}

Psychologists engaged in research on participation have argued that participation, power, and responsibility on the job tend to satisfy basic ego needs. Having the power of participation, implies to workers that they are equal partners, collaborators in an organization rather than passive, coerced, and unwilling subordinates. Kreitner \& Kinicki (2010) remarked that participation strengthens the belief, or creates it, that the workers are worthy of being consulted; that they are intelligent and competent. When management make the frequently bitter remarks that 'they do not pay you to think around here', they are really saying that their opinions are not valued; that they are not regarded as competent collaborators, but merely as living automations, passive extensions of the machines they operate. Participation corrects this by gratifying the basic human needs for respect, appreciation, responsibility, and autonomy (Jaroslav, Reibel, \& Blumberg, 1975).

In the light of the foregoing, that the participating workers are involved workers, for their jobs become an extension of themselves and by their decision, they are creating their work, modifying and regulating it. As they are more involved in their works, they become more committed to it, and being naturally derived more satisfaction from it. What is more democratic and by extension, the bedrock of harmonious relationship in industrial setting amongst actors that make the system more than the above? Okon (2008) asserts that, one greatest way of ensuring industrial democracy and harmonious relationship in the organization, is to create an institution within society that can challenge the prevailing structure, where management see themselves as super-masters and anticipate the new; where co-operation, interrelatedness and interdependency in all manner amongst partners will be observed. According to Alan (1970), people within such institutions must learn ways of thinking and acting that distance them from behaviors, not appropriate to presently existing system and train them in ways more appropriate to instill discipline in the society. These institutions must be that which encourage equality, democracy and cooperation in the system. These institutions will direct their efforts towards effective and efficient transformation of people's (workers') mind and management super attitudes cum government ideology including culture and the creation of means of achieving fairness and understanding at workplace (Jaroslav, Reibel, \& Blumberg, 1975).

A type of democratic institutions or structure with good and sound educator having the mandate not only to subject presently existing quasi- capitalist Nigeria leaders to criticism, but also to offer a clearly articulated vision of a better society that will ensure industrial peaceful existence and to help create and generate from within workers, management and government the understanding, skills, capacities, and intelligence necessary for the task of creating a new socio-economic, cultural and political order. This can be possible when the new movement for change, identify, encourage and train a stratum of technical, scientific, and literary personnel from within the working class, management, and government will create counter order institutions in the midst of existing society that would train people for the new order (Edward, 1986). Industrial harmony only applies if organizations are owned by workers and managed as in the selfmanagement system in transitional Socialist Yugoslavia. There, each plant is managed by a board of management elected by workers (Okon, 2008). This therefore suggests that, if workers are allowed to make some suggestions based on their work experiences about how production or sale may be improved, that does 
not give us industrial relations harmonious atmosphere. It is a mere suggestion and far from been decision in itself.

In conclusion, management/employers should understand and appreciate the fact that labour (workers) is not mere commodities or mere supply of labour force at the shareholder and management/government disposal. Essentially, labour is the real basis that underlies the production of goods and services. Through their work, the human personality and its sense of responsibility are able to be unfolded. Employers/management should therefore appreciate this and attribute its success to the trained and efficient labour force. Fundamentally, labour should be given the power or right of say in the affairs of the business and the organization, not only in the field of labour condition and labour environment, but in all aspects or spheres of the business administration and policy, and should effectively make useful input that shows it's a desirable partner. As necessary component to ensuring industrial harmony, it behooves both employers and employees to create a working culture that gives credence to collaborativeness and team spirit. It is factual that when people of diverse background and experience and as well as different interests converge together at a workplace to attend to problems, share ideas, with a focus on creativity, rewards system, innovativeness and the satisfaction of members, the end result will be positive. This is because they brought to bear their self-worth and identity and thus avert the challenges of work-life-balance, therefore providing a desiring vantage position for organizations optimum progress, growth and development and as well as other social partners (Aishali, 2012). The creation of the scenario presented above, according to Izidor (2015) implies a situation whereby employees actively participate in achieving the set goals and objectives of organizations, thereby drastically reducing tensions at workplace. This is seen as harmony booster and should be encourage and adopted to achieve industrial peaceful co-existence; Organizations structured this way will develop the culture of industrial social order which is essential for organizational productivity

Another considerable bedrock that is a critical issue in the enthronement and fostering of industrial peace is the structuring of effective communication channel wherein, flow of information will not be distorted by autocratic boss master leading to dissatisfaction of the affected party(s) (Nwinyokpugi, 2014). In this case, if employees are adequately and timely informed of matters concerning all, and also have the opportunity to meeting those at the helm of affairs to discuss common ground, issues that would have generated to conflict/crisis would have been nipped in the bud before breaking limits (Miebaka, 2002). Supporting the above, Iheriohanma (2008) emphasizes on the need for restructuring process of communication to where the impact of global interest in the issue of democratization can be felt by all cadres in the organization concerns. This implies the restructuring of the rigid authoritarian management model of communication to evolve the application of strategy that will accommodate top-down and bottom-up synergy where workers are given unhindered flow to employer in decisions concerning them (Iheriohanma, 2007). According to Izidor (2015), considering the circumstances of the issue of globalization in all round affairs of human social existence competitively, there is an absolute necessity that industrial organizations adopt the principle of participatory management to enthrone industrial harmony. Kreitner \& Kinicki (2010), said of participatory management to mean a process that gives employees a direct role in setting goals, contribute in making decisions, and involve in providing solution to solving problems confronting social partners.

Work place harmony, which is the pivot for industrial peace is necessary in a future social order that is decent and humane, in the political movement that will help to bring it to reality. Indeed, a mutually reinforcing relationship may be relevant for not only is work place democracy an essential part of such future society and the movement to bring it to fruition, but it is only within this nurturing environment that the bright promise of workplace democracy and harmonious relationship may be realized (Nkiinebari, 2015). The end of alienating labour, creation of educated, engaged and empathetic citizenry, and the encouragement of a self-confident working people is pertinent to a harmonious and productive organization (Edward, 1986). Workplace harmony and industrial democracy can realize its bright expectations only in environments characterized by democracy, equality, fraternity etc and not where management and/or employers through government uses its resources or state apparatus as means of terrorizing workers even when they are making legitimate demands (Olufemi, n.d.). 
Fundamentally, what will ensure sound principle and practice of industrial harmony is equality in organization and of society which according to Nkiinebari (2014) should be in a manner that ensure that the resources produced by the society through its workforce are distributed to meet the common needs of its members. Exact mathematical equality is neither possible nor necessary; but all members of the society must share in the enjoyment of those goods and services produced by society which are requisite of a life of decency, fulfillment, and self respect. Recognizing that production is the outcome of the shared contribution of the skills, intelligence and labour of the workers; government laws and budgetary allocation, distribution of the fruits of production should take majoritarian form as well and not be hoarded in the hands of the few or take away by government harsh policies (Edward, 1986).

Achieving workplace democracy and harmonious relationship at work among participants will involve democratizing organizational decision-making beyond the level of representative industrial democracy. Such shared decision-making system, will give workers' enormous rights in determining both employment contract and labour utilization rules at workplace (Aderemi, 2007). This will generate in the workers of the organization a great sense of responsibility and commitment at work. The principle of industry democracy and harmony imply that workers will no more see themselves as passive objects, but rather, as participants in the affairs of the organization (Augustine, 1999). "...Industrial democracy consists; in part, of the opposition of the trade unions to the employer, and in part, of the attempt of the employer to build his employees into a team working together towards a common purpose..." (ibid).

From this premise, he goes on to make a direct analogy from politics to industry. He stated, just as political democracy is based on the existence of an opposition for proper, smooth and functional government in power; so also, industrial democracy is contingent upon the existence of an opposition within the industry to the prevailing power of management or ownership. What constitutes an effective industrial opposition is a strong trade union organization. The trade union within the organization is to management what the opposition political part is to government in power. Indeed, it is logical therefore, that if industrial democracy consists of no more than trade union opposition and a management which accepts this opposition, then certainly this type of industrial democracy and peaceful co-existence, will in no small measure enhance productivity and performance on the side of the workers and management that is responsive and workers who are friendly will thrive.

\subsection{Mutual Bargaining As A Mechanism For Compromise}

Collective bargaining is defined as all the negotiations and consultations that take place between the workers represented by their unions for determining all aspects of working conditions including wages, jobs security, welfare and production of work. The relative bargaining power possessed and exhibited by each, forces the other party to be aware of the implications or its actions and to think bilaterally (Clement, 2014). More specifically, collective bargaining is the procedure by which an employer or employers and a group of employees agree upon the conditions of work (Armstrong, 2005). Accordingly, Fashoyin, (1992) see collective bargaining as machinery for discussion and negotiation, whether formal or informal between employer(s) and workers representatives aimed at reaching mutual agreement or understanding on the general employment relationship between the employer(s) and workers. Therefore, the acknowledgement of this power carries with it the right to be listened to. In effect each party makes its decision bearing in mind the possible reactions of the other party. Collective bargaining establishes what is generally regarded as industrial jurisprudence in the workplace. The basis of collective bargaining is joint authorship of the work roles by the union and the management which comes out in the form of a collective agreement. The collective agreement specifies the rights and obligations of workers individually and management against the arbitrary treatment/ regimentation of the union leadership. It is worthy of note that collective agreement has a built-in flexibility to provide for issues not covered by the collective agreement (Peretomode \& Peretomode, 2001). Another way the collective bargaining introduces industrial harmony in the workplace is that through their union made up of their elected representatives, the individual worker makes contributions to the union relations with the management. In effect, the point being made is that collective bargaining therefore provides the means by which workers influence the industrial relations policy of management through logical and informed ideas when dialoguing collectively (Clement, 2014). Collective bargaining has really helped 
the employers to gain insight into the problems and aspirations of the workers, while the workers on their own come to know more about the economic and technical problems of management (Peretomode \& Peretomode, 2001). It is also wise to note that, through the time consuming and tortuous process of collective bargaining, the emotionally charged workers or their representatives (Trade union) and employers or their representatives have time to cool-off and soften their problems. Thus, this has pave way for industrial democracy and peaceful coexistence (Fashoyin, 1992).

According to Ubeku (1983), collective bargaining is based on the principle that workers have a right to contract with their employers as to ways and conditions of work and that the employer recognize that right. In effect, it serves as a system of wage and condition of service determination in which the employer shares administrative decision making responsibilities with the union. The collective bargaining process manifests the power relationship between unions and employers on issues directly affecting conditions of employment. It is also a means of limiting unilateral decisions and actions by employers and government. Strong, stable, and well focused and democratic unions expand the scope of collective bargaining and thereby strengthen industrial democracy and harmony (Otobo, 1988). Ron (2004) posit that collective bargaining is in fact a multifaceted institution which internationally has diverse meanings and functions. In addition to rulemaking, which reduces the degree of uncertainty confronting workers and management, it can also be a vehicle for resolving disputes, a power relationship, a form of joint industrial government and channel to addressing conflict. A central integrating mechanism viewed as medium that provides industrial harmony and peaceful industrial atmosphere at resolving conflicting matters at workplace between trade unions i.e. workers' representatives and management which represent employers' interests.

Girigiri (2008) remarked that collective bargaining is a process that replaces the individual worker's usually feeble attempt to gain improvements for himself, and is rather based upon the cumulative and pooled experience of many workers, thrashed out through their union, co-ordinate into a single programme, and backed by their collective strength; and it is bargaining; because at any one time the programme is adoptable to the practical situation, and because there is a constant process of give and take of experience and of views, and positions. The knowledge of both trade unions and management in collective bargaining issues being that of complementary, where "each side yielding in and gaining at a point then the end result has the more practical strength of both point of views; richer and more pointed to the collective issues that informed the bargaining between parties (Yesufu, 1984). Again, collective bargaining presumes mutual consent and recognition by parties concerned through their representatives of each party interest. In the instance, a measure of autonomy and the right of such interests are certainly to be protected against trespassing each other's rights. The protection of interest assumes a capacity to do so, namely, an element of power, which is assumed to be fairly distributed, hence making possible a bargaining situation (Otobo, 1988). The above point to the fact that the matters were collectively discussed, analyzed and finally agreed upon and it will be binding on all parties. No individual workers can at any point be punished and/or on his/her own challenge management on issues covered in the bargaining except management acting counter wise with a sinister motive undermine the collective but agreeable decision reached.

\subsection{Conclusion}

This paper discusses labour-employer-management relationship with specific focus on how to create industrial harmony in the workplace. It began with introductory aspect that spelt out some essential ingredients for the socio-economic, political and cultural developments for the Industrial Relations, but are lacking in industrial relations system in Nigeria. In the context of this paper, some measures that can bring about good Industrial harmony among the actors were clearly discussed for instant, decision-making processes which should go beyond that of representatives to where workers have enormous rights in determining both employment contract and labour utilization in the work place. Furthermore, creation of democratic institutions or structures with good and sound educators having the mandate not only to subject presently existing quasi-capitalist Nigeria leaders to criticism but also to offer a clearly articulated vision of a better society, where workers, management and government will understand themselves. A system were management or government accept trade unions opposition as a true vanguard for industrial best practices and development, as government see the opposition political parties as watch-dog to their polices and conducts. The causes of industrial discontent among the actors were equally discussed. Since trade unions 
and management have diagonally opposing interests, conflict is inevitable. Conflict sometime occur between workers and unionists and management themselves over certain unresolved issues. However, the most remarkable is that between trade union and management. The real essence of collective bargaining as one of the tools to amicably settled dispute was not left out. It has helped trade unions and management to gain insight into problems confronting each other and thus shift ground for accommodation. It also reduces and replaces individual worker feeble attempt to gain recognition or improvements, but rather based on strength for general workers' interests.

\section{References}

Aderemi, A. (2007). Industrial harmony as a tool for enhancement of productivity. Paper Presented at a Twoday seminar on the 'Role of Management and Trade Union Towards peaceful relationship and improved productivity', at the Mega class hotel and suites at Port Harcourt, from 23 ${ }^{\text {rd }}-24$ th November, 2007.

Agba, A.M.O., Ushie, E.M. \& Agba, M. S. (2009). External factors in industrial crisis in the Nigeria service. Nigerian journal of labour and industrial relations. 3(3), 75-94.

Alan, F. (1970). A Sociology of work in Industry. London: Collier Macmillan Publishers.

Albert, T.A. \& Yahaya, M.A. (2013). Challenges and prospects of effective industrial conflict resolution in Nigeria. Journal of Social Science, 36(2), 199-208.

Alo, O.I. (1999). Human Resources Management in Nigeria. Lagos business and Institutional support associates limited.

Arun, M. (2007). Industrial relations. New Delhi: Tata McGraw-Hill publishing company limited.

Augustine, A. (1999). The African Industrial man. Port Harcourt: CIMRAT Publications.

Badom, M. P., Anele, K. A. \& Badey, D. (2018). Oil and gas workers' industrial actions as precursor of development in Nigeria. International journal of social science and humanities research. 6(4), 835843.

Badom, M. P. (2019). Oil and gas workers' industrial actions and impacts on commuters in Rivers State, Nigeria. (PhD thesis). School of graduate studies, university of Port Harcourt, Nigeria.

Bello-Iman, T. B., Mike T. O. (2004). Democratic government and development management in Nigeria's fourth republic 1999-2003. Ibadan: Centre for local government and development Studies (CLGRDS).JODAD Publishers.

Charles, N.O. (n.d.). Trade unionism, collective bargaining and nation building The Nigeria experience, paper presentation.

Clegg, H.A. (1960). A New approach to industrial democracy. Oxford: Blackwell.

Clement, A. A. (2014). Fundamentals of Industrial and labour Relations. Enugu: RhyceKerex Publishers.

Dabibi, M. G. (n.d.). Labour law, democracy and Industrial harmony: Towards Industrial peace in Nigeria. Paper Presentation.

Damachi, U. \& Fashoyin, T. (1986). Contemporary problems in Nigeria Industrial relations. , Lagos: Development press limited.

Edward, S. G. (1986). Workplace democracy: The political effects of participation Ithaca, London: Cornell University Press.

Eghosa, O., Aneesa, K., Austin, I. etal (1994). Between state and civil society in Africa: perspectives on development. Dakar: CODESRIA book series.

Girigiri, B. K. (1999). Industrial organization: A sociological perspective. Owerri: Springfield Publishers.

Girigiri, B. K. (2008). Globalization: The state and trade unions in Nigeria. A political economy of trade unions Act (Amendment) Act, 2005. Port Harcourt: Amethyst cord colleagues publishers.

Girigiri, B .K. (2002). Industrial relations in Nigeria: Issues in public sector crises. Port Harcourt: Amethyst and colleagues publishers.

Girigiri, B. K. (2007). Globalization and industrial relations in Nigeria: Evidence from 1986-2006. Nigerian journal of labour law and industrial relations. 1(2).

Haralambos, M. \& Heald, R. M. (1980). Sociology: Themes and perspectives. Oxford: University press.

Haslam, N. (2006). Dehumanization: An integrated review. Personality and social psychology review, 10(3), 252-264.

Iheriohanma, E. B. J. (2007). The socio-economic issues challenging workers' participation in management and productivity in Nigeria. IKOGHO: A multi-disciplinary Journal. 4(4), 1-11. 
Imaga, E. U. L. (2004). Industrial democracy in the third world. Enugu: Phycekerex Publishers.

Issa, G.S., Kapinga, W. B. L. \& Mwakyembe, H. G. (1986). The state and the working people in Tanzania. Dakar: CODESRIA.

Jaroslav, V., Reibel, R. \& Blurnberg, P. (1975). Self-management: Economic liberation of man. England: Penguin education.

Karl, M. (1990). Manifesto of the communist party. Beijing: Foreign Language Press.

Kreitner, R. \& Kinicki, A. (2010). Organizational behaviour. New York: McGraw-Hill Publishers.

Makinde, H.O. (2013). Securing a harmonious working environment through effective industrial relations of workplace. The Nigerian perspective. Business management dynamics. 3(3), 46-89.

Mayowa, S.O. (2015). Industrial conflict and its management in selected Nigerian manufacturing companies. International Journal of Organizational Leadership. 4.

Armstrong, M. (2005). A handbook of human resource management practice. New Delhi: Kogan Page Limited.

Miebaka, D. T. (2002). Managing human resources basic principles. Owerri: Civines publishers.

Mukoro, S. A. (2013). Industrial harmony and staff performance in a school organization through effective communication. International Journal of Scientific Research in Education. 6(3), 263-270.

Nkiinebari, N. P. (2014). Workplace democracy and industrial harmony in Nigeria. International journal of innovative research and development. 3(1).

Nkiinebari, N. P. (2015). Employee engagement and workplace harmony in Nigeria Civil Service. International journal of innovative research and development. 4(2).

Nwibere, B. M. \& Emecheta, B. C. (1990). Organizational development and change: Principles, processes, practice. Port Harcourt: Sherbrooke Associates Publishers.

Nwinyokpugi, P. N. (2014). Workplace democracy and industrial harmony in Nigeria. International journal of innovative research and development. 3(1).

Nwokocha, I. (2014). Sustainable managerial strategies for employees retention in two private sector organizations in Port Harcourt, Rivers State, Nigeria. (PhD Thesis), Ebonyi State university, Nigeria.

Okon, E. U., Oyovbaire, S., \& Victor, U. etal (2008). Civil society and the consolidation of democracy in Nigeria. Calabar: CATS publishers.

Olufemi, R. E. (n.d.), Trade unions and maintenance of industrial peace in the $21^{\text {st }}$ century: Issues and prospects. Paper presented at national workshop on 'labour dispute management and industrial arbitration'.

Onuegbu, C. (2014). Social dialogue: Industrial harmony and national development. This Day Newspaper, p. 6.

Osabuohien, E. S. \& Ogunrinola, I. O. (2007). Cause and effects of industrial crises in Nigeria.

Otobo, D. (1988). State and industrial relations in Nigeria. Lagos: Malthouse press limited.

Otobo, D. (2000), Industrial relations: Theory and controversies. Lagos: Malthouse press limited.

Otobo, D. (2005). Industrial relations: Theory and controversies. Lagos, Malthous Press Ltd.

Ron, B. (2004), Comparative industrial relations: An introduction to cross national perspectives. USA: Routledge.

Samwonyi, F. \& Ugiaghe, E. O. (2013). Harmonious industrial relations as a panacea for ailing enterprises in Nigeria. Journal of Asian Scientific Research, 3(3). 229-246.

Tinyemiema, J. K. (2008). Effective conflict resolution mechanism for enhanced productivity in the oil and gas industry. proceedings of NUPENG Eastern Zonal Conference. Enugu, Nigeria.

Ubeku, A. K. (1983). Industrial relations in developing countries: The case of Nigeria. London: Macmillan.

Vaishali, C. (2012). Current trends in employee retention strategies. International journal of new practices in management and engineering. 4(1), 20-27.

Webb, S. \& Webb, S. (1919), Industrial democracy. London: Longman.

Yesufu, T. M. (1984). The dynamics of industrial relations: the Nigeria experience. Ibadan: University Press Limited. 